\title{
PEMANFAATAN TITANIUM DIOXIDE PADA TROTOAR UNTUK MENGURANGI GAS PENCEMAR NOx DI UDARA
}

\author{
Hafizhul Khair AM ${ }^{1}$, Kania Dewi ${ }^{2}$ dan Moh. Irsyad ${ }^{3}$ \\ ${ }^{1}$ Program Studi Teknik Lingkungan, Universitas Sumatera Utara \\ ${ }^{2,3}$ Program Studi Magister Teknik Lingkungan, Institut Teknologi Bandung \\ Email: hafizhul@gmail.com
}

\begin{abstract}
ABSTRAK
Sektor transportasi merupakan salah satu penyumbang pencemaran udara terbesar di Indonesia, terutama di kota-kota besar. Gas-gas hasil pembakaran bahan bakar kendaraan bermotor seperti oksida nitrogen $\left(N O_{x}\right)$ akan diemisikan ke udara ambien. Meningkatnya konsentrasi $N O_{x}$ di udara ambien dapat berdampak buruk bagi kesehatan manusia terutama berkaitan dengan penyakit saluran pernafasan bagian atas. Karena itu, pengembangan metode-metode yang ramah lingkungan untuk mengendalikan pencemaran udara harus dilakukan. Salah satu cara sederhana menurunkan pencemaran udara adalah memanfaatkan proses yang murah, yaitu sinar matahari dan efek katalis dari $\mathrm{TiO}_{2}$, untuk mengendalikan $\mathrm{NO}$ dan $\mathrm{NO}_{2}$. Metode ini tidak memerlukan energi tambahan selain sinar ultraviolet yang berasal dari matahari. Paving block berlapis $\mathrm{TiO}_{2}$ dipaparkan di udara ambient dalam waktu 6 jam, 12 jam, 18 jam dan 24 jam. Ion nitrat dan nitrit yang terbentuk akibat proses fotokatalitik di permukaan paving dilarutkan dengan aquades yang kemudian diukur dengan ion chromatografi. Hasil percobaan menunjukkan bahwa dengan tambahan $\mathrm{TiO}_{2}$ sebanyak 200 gram untuk setiap meter persegi paving mampu mengadsorpsi gas $\mathrm{NO}_{x}$ dengan laju adsorpsi rata-rata sebesar 0,0046 $\mathrm{mg} / \mathrm{m}^{2} /$ menit, peningkatan konsentrasi $\mathrm{HNO}_{3}{ }^{-}$seiring dengan lamanya proses pemaparan di lapangan. Biaya tambahan untuk setiap meter persegi paving block yaitu Rp. 13180.
\end{abstract}

Kata kunci: fotokatalitik, ion nitrat, ion nitrit, oksida nitrogen $\left(\mathrm{NO}_{x}\right)$, titanium dioksida $\left(\mathrm{TiO}_{2}\right)$, paving block

\begin{abstract}
The transportation is one of the largest contributor to air pollution in Indonesia, especially in large cities. Fuel gases from combustion in motor vehicles, such as oxides of nitrogen $\left(N O_{x}\right)$ will be emitted to the ambient air. Increasing the concentration of $N O_{x}$ in ambient air can be bad for human health, especially with regard to upper respiratory tract disease. Therefore, the development of methods which are environmentally friendly for controlling air pollution remains to be done. One simple way to reduce air pollution is utilizing a cheap process, namely sunlight and effect of catalyst of $\mathrm{TiO}_{2}$, to control the $\mathrm{NO}$ and $\mathrm{NO}_{2}$. This method requires no additional energy in addition to ultraviolet rays coming from the Sun. Paving-coated $\mathrm{TiO}_{2}$ ambient air set out in 6 hours, 12 hours, 18 hours and 24 hours. Nitrate and nitrite ions are formed by photocatalytic on the surface of the paving is dissolved with the aquades which is then measured by ion chromatography. The experimental results showed that the composition of $\mathrm{TiO}_{2}$ $200 \mathrm{~g} / \mathrm{m}^{2}$ of paving is able to adsorp $\mathrm{NO}_{x}$ gas at an average rate of $0.0046 \mathrm{mg} / \mathrm{m}^{2} / \mathrm{minutes}$, elevated concentrations of $\mathrm{HNO}_{3}{ }^{-}$along with the duration of exposure. Additional costs for every square meter paving is $R p .13180$.
\end{abstract}

Keywords: Photocatalytic, nitrate ion, nitric ion, nitrogen oxides ( $\mathrm{NOx}$ ), titanium dioxide ( $\mathrm{TiO}_{2}$ ), paving

\section{PENDAHULUAN}

Penggunaan bahan bakar pada kendaraan bermotor menghasilkan emisi zat pencemar seperti oksida nitrogen (NOx). Udara yang tercemar dapat mengganggu kesehatan manusia, tergantung dari macam, ukuran dan komposisi kimiawinya. Gangguan tersebut terutama terjadi pada fungsi faal dari organ tubuh seperti paruparu dan pembuluh darah, atau menyebabkan 
iritasi pada mata dan kulit. Efeknya yang lebih parah lagi adalah bisa menyebabkan kanker paru-paru, keguguran, dan menyebabkan kematian dini. Selain itu reaksi fotokimia dari sinar matahari dengan NOx bisa menimbulkan polutan jangka panjang, seperti hujan asam yang berbahaya bagi bangunan (korosi) dan vegetasi. Oleh karena itu harus ada usaha untuk mengurangi pencemaran udara yang terjadi dengan pengembangan metode-metode yang ramah lingkungan.

Salah satu cara mengurangi pencemaran udara khususnya NOx bisa menggunakan reaksi fotokatalik dari $\mathrm{TiO}_{2}$, yaitu memanfaatkan efek katalis dari $\mathrm{TiO}_{2}$ dan sinar ultraviolet dari matahari sebagai aktivasinya, reaksi fotokatalis mengendapkan polutan yang teroksidasi pada permukaan material kemudian memanfaatkan air hujan sebagai pembersihnya. Mekanisme proses fotokatalitik pada permukaan yang dilapisi $\mathrm{TiO}_{2}$ dapat ditunjukkan pada Gambar 1 .

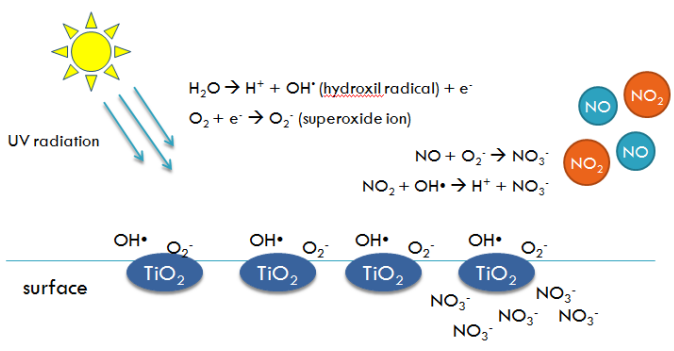

Gambar 1. Mekanisme proses fotokatalitik pada permukaan yang dilipisi titanium dioksida

(McForet, 2012)

$\mathrm{TiO}_{2}$ adalah material logam, yang hadir di alam dalam berbagai bentuk. $\mathrm{TiO}_{2}$ memiliki tiga molekul yang berbeda struktur yaitu: rutil, anatase dan brookiet (Fujishima, dkk., 1999.). Rutile dikenal sebagai pigmen putih cat, tapi mempunyai reaktivitas fotokatalitik rendah. Anatase adalah lebih baik jika digunakan sebagai fotokatalitik. Untuk menggunakan anatase sebagai fotokatalis, diperlukan sinar ultraviolet (UV) dengan panjang gelombang lebih rendah dari $387 \mathrm{~mm}$.

Sumber ultraviolet di alam berasal dari sinar matahari, spectrum radiasi UV dibagi menjadi beberapa kelompok. Radiasi UV dengan panjang gelombang $400 \mathrm{~nm}-320 \mathrm{~nm}$ disebut "UV-A", panjang gelombang 320 - $290 \mathrm{~nm}$ disebut "UV-B" dan panjang gelombang 280 $100 \mathrm{~nm}$ disebut "UV-C". Radiasi UV pada gelombang pendek lebih kuat diserap oleh banyak jenis pencemar dan biomolekul. Intensitas UV diukur untuk melihat jumlah radiasi yang dihasilkan dari sinar matahari. Intensitas UV mencapai puncaknya pada jam 12 siang sebagaimana yang ditunjukkan pada Gambar 2 (Diffey, 2002), yaitu variasi hasil pengukuran intensitas UVA dan UVB di Inggris.

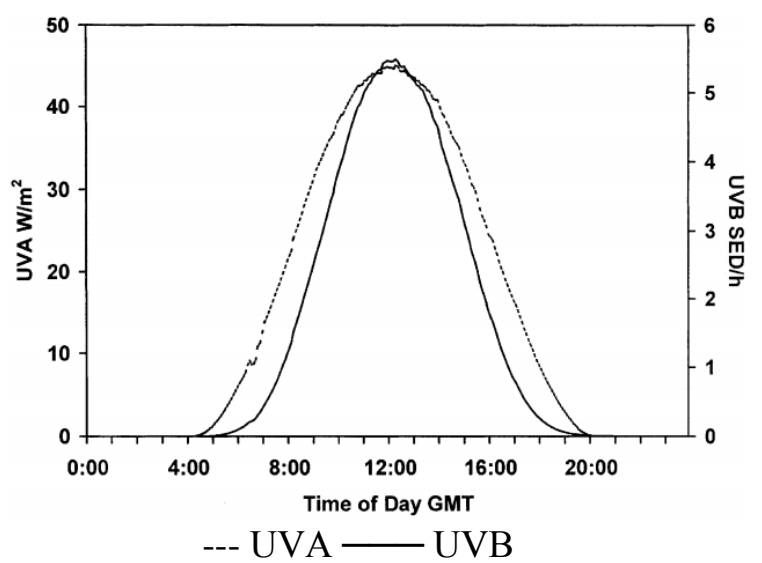

Gambar 2. Variasi Intensitas UVA dan UVB

Saat Musim Panas di Inggris (Diffey, 2002)

Pada kasus $\mathrm{TiO}_{2}$, panjang gelombang yang lebih kecil dari $400 \mathrm{~nm}$ diperlukan untuk iradiasi, yang sesuai dengan spektrum UV dari matahari. Intensitas yang lebih tinggi menghasilkan lebih banyak foton yang dihasilkan, sehingga tingkat oksidasi fotokatalitiknya lebih tinggi (Fujishima dkk., 2000, Zhao dan Yang 2003). Hubungan antara intensitas dibandingkan tingkat oksidasi fotokatalitik seringkali menunjukkan korelasi linear. Tingkat kenaikan tergantung pada polutan kimia. Misalnya, ketika radiasi berubah $0-1500 \mu \mathrm{W} / \mathrm{cm}^{2}$ efeknya adalah linier. Oksidasi fotokatalitik TCE meningkat dari $0,08 \times 10^{-6}$ menjadi $0,25 \times 10^{-6} \mathrm{~mol} / \mathrm{s}$ gram sebagai akibat intensitas cahaya yang meningkat dari 0,08 $\mathrm{mW} / \mathrm{cm}^{2}$ menjadi $0,45 \mathrm{~mW} / \mathrm{cm}^{2}$ (Zhao dan Yang 2003).

Fotokatalis ini dapat diterapkan dalam berbagai bentuk termasuk pada modul semen, dengan cara menambahkan lapisan tipis di atas permukaan modul semen tersebut. Cukup sering, jenis pelapis ini disebut sebagai "self cleaning coating", karena lapisan fotokatalitik pada bahan konstruksi bertindak untuk 
mencegah dan juga mengadsorp debu yang cenderung menempel pada permukaan kotor (Paz, 2010).

Ketika oksidasi fotokatalitik yang terdekomposisi diserap pada di permukaan, permukaan dibersihkan dan diubah menjadi sangat hidrofilik (Hashimoto, dkk., 2005). Noda yang menempel pada permukaan hidrofilik $\mathrm{TiO}_{2}$ dapat dibersihkan dengan mudah, karena adanya memiliki kemampuan "self cleaning" tersebut. Beton fotokatalitik mulai banyak digunakan pada proyek-proyek teknik arsitektur dan sipil di Eropa dan Asia sebagai bahan pembersihan diri. Beberapa manfaat konsentrat fotokatalitik adalah mampu mengurai bahan kimia yang berkontribusi sebagai penyebab kekotoran dan polusi udara, menjaga kebersihan beton, dan mampu memantulkan banyak panas matahari sehingga mengurangi panas karena warna $\mathrm{TiO}_{2}$ yang putih (Shen, dkk., 2012).

Bahan material/bangunan yang memanfaatkan proses fotokatalitik telah banyak digunakan diberbagai lingkungan indoor dan outdoor, tujuannya yaitu untuk mengurangi konsentrasi NOx di udara. Misalnya dalam $30 \mathrm{~m}^{3}$ ruangan, pada $30^{\circ} \mathrm{C}$ dan kelembaban $50 \%$, dan di bawah radiasi UV 2,1 W/m $\mathrm{m}^{2}$ cat komersial ditambah dengan $\mathrm{TiO}_{2}$ sebanyak 3\%, dicapai pengurangan konsentrasi NOx sebesar 0,21 mg/m (Maggos, dkk., 2005). Pada kondisi yang sama cat translucent yang mengandung $\mathrm{TiO}_{2}$ sebanyak 5 $\%$ mampu mengurangi kosenstrasi NOx sebesar $0,06 \mathrm{mg} / \mathrm{m}$.s. Demikian pula lantai yang dilapisi dengan lapisan $\mathrm{TiO}_{2}$ dilaporkan mampu untuk menghilangkan polutan NOx (Toulan, dkk., 2006).

Untuk removal NOx di luar ruangan, dalam satu studi fotokatalitik paving mampu menurunkan 15 persen oksida nitrat yang dilepaskan oleh kendaraan di jalan raya dan ini lebih efektif, selain menanam pohon di kedua sisi jalan. Pendukung lainnya dari pemanfaatan teknologi baru dimana menunjukkan bahwa kualitas udara perkotaan dapat ditingkatkan hingga 80 persen jika semua jalan, trotoar, dan permukaan eksterior bangunan dirawat dengan baik (Chusid, 2005).

Saat diuji di lingkungan luar, hujan mampu memberikan efek dalam regenerasi fotokatalitik, mirip dengan pembilasan. Akibatnya, beberapa merekomendasikan pembilasan dilakukan setidaknya setiap dua bulan selama musim kemarau (Yu, 2002). Namun, air bilas atau hujan belum efektif dalam penempelan kontaminan ke material dan air larutan kontaminan. Akibatnya, menggunakan agen degreasing mungkin bisa bermanfaat. Solusi lain yang diusulkan dari Zhao adalah meningkatkan suhu permukaan atau air bilas untuk menghilangkan intermedit dan mengembalikan sisi aktif pada permukaan katalis (Zhao dan Yang, 2003). Meskipun masih terjadi perdebatan, satu hal di mana penelitian setuju bahwa daya tahan aktivitas katalitik harus dibuktikan untuk implantasi yang luas dan teknik regenerasi, yaitu menerapkan air bilas harus dievaluasi jika terjadi degenerasi (Berdahl dan Akbari, 2008).

Total porositas pada permukaan paving yang dilapisi $\mathrm{TiO}_{2}$ mengalami penurunan dan pengurangan volume pori, dimana hal ini terjadi pada rentang pori kapiler. Selain itu terjadi percepatan tingkat hidrasi dan perubahan mikrostruktur yang juga mempengaruhi sifat fisik dan mekanik dari paving tersebut (Chen, dkk., 2012).

Keberhasilan komersialisasi permukaan berlapis $\mathrm{TiO}_{2}$ dengan kemampuan self cleaning pada beton, kaca dan produk keramik. Dengan capaian yang memungkinkan produk tersebut terjaga dari segi penampilan dan estetika dari waktu ke waktu (Chen dan Poon, 2009).

\section{METODOLOGI}

Penelitian dilakukan pada skala lapangan, pembuatan dan penyiapan paving block yang siap digunakan di lapangan, kemudian diuji performanya, mengolah dan menganalisis data, data diperoleh dari hasil parameter-parameter yang diukur kemudian dianalisa dengan membuat tabulasi secara kualitatif.

Lokasi sampling untuk pengujian lapangan fotokatalitik $\mathrm{TiO}_{2}$ dilaksanakan di perempatan Taman Cikapayang di Jalan Ir. H. Juanda, Bandung. Lokasi ini dipilih karena berada diperempatan jalan dengan tingkat kepadatan lalu lintas yang tinggi. Untuk lebih jelasnya, lokasi sampling, skema dan percobaan di 
lapangan dapat dilihat pada Gambar 3, Gambar 4 dan Gambar 5.

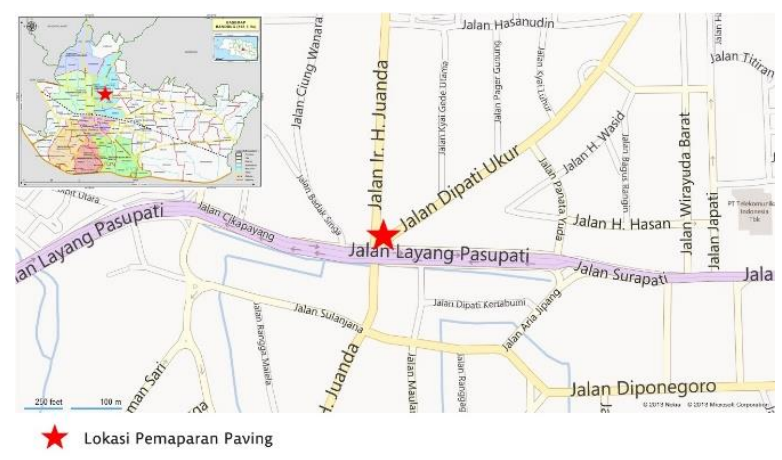

Gambar 3. Denah Lokasi Sampling Pengujian

Fotokatalitik $\mathrm{TiO}_{2}$ di Lapangan

Tahap awal penelitian adalah menentukan komposisi campuran optimum $\mathrm{TiO}_{2}$ dan kemudian dilanjutkan dengan pembuatan paving berlapis $\mathrm{TiO}_{2}$.

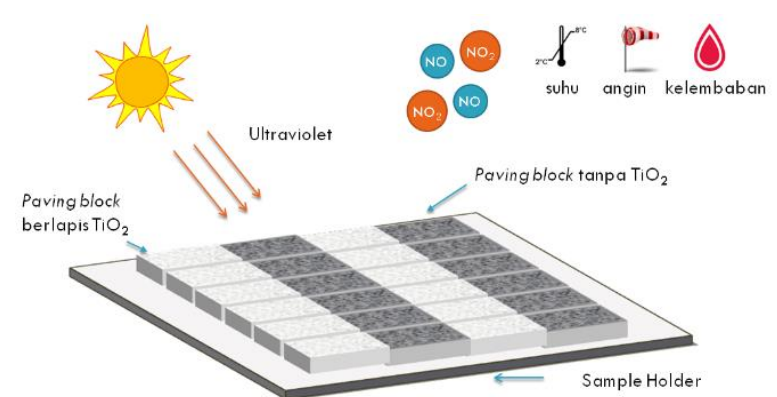

Gambar 4. Skema Fotokatalitik Paving Block Berlapis $\mathrm{TiO}_{2}$ di Lapangan

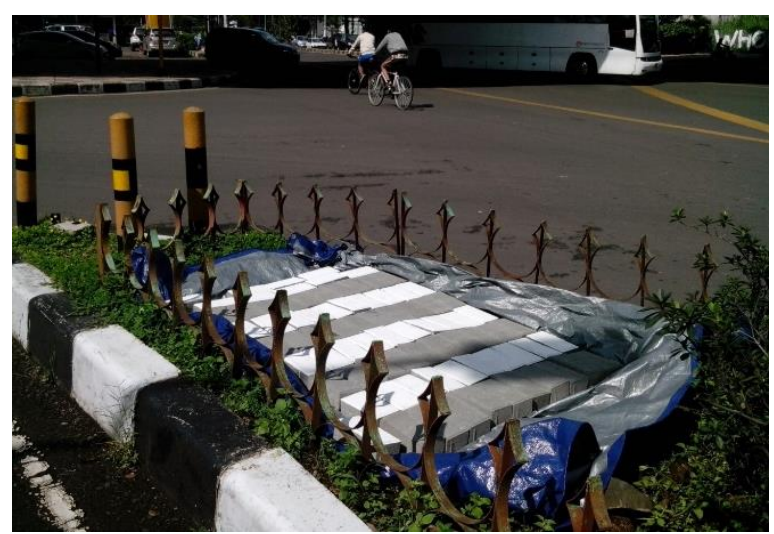

Gambar 5. Pemaparan Paving Berlapis $\mathrm{TiO}_{2}$ di Jalan Ir. H. Juanda Bandung

\section{Penentuan Komposisi Optimum Campuran $\mathrm{TiO}_{2}$}

Pada tahap awal dilakukan percobaan untuk menentukan komposisi optimum campuran $\mathrm{TiO}_{2}$ yang akan digunakan untuk melapisis bagian atas paving. Penentuan komposisi optimum ini berguna untuk mencari formula yang tepat untuk menempelkan $\mathrm{TiO}_{2}$ ke permukaan paving dengan baik. Pada penelitian ini digunakan water based resin untuk mambantu mengikatkan $\mathrm{TiO}_{2}$ ke permukaan paving. Penentuan komposisi campuran optimum lapisan $\mathrm{TiO}_{2}$ terhadap water based resin dilakukan dengan 3 tahap pengujian yaitu terdiri dari perlakuan awal (secara fisik dengan menggesekkan jari pada permukaan paving yang dilapisi $\mathrm{TiO}_{2}$ untuk mengetahui tingkat kerekatan lapisan $\mathrm{TiO}_{2}$ pada paving block), uji ketahanan aus dan perhitungan biaya komposisi campuran. Maka dari itu dibuatlah berbagai variasi komposisi $\mathrm{TiO}_{2}$ yang memungkinkan dan dilakukan pengujian.

\section{Spesifikasi Paving Block}

Spesifikasi kualitas paving yang digunakan mengacu pada SNI 15-6699-2002, syarat mutu, cara pengambilan contoh, cara uji, syarat lulus uji dan syarat penandaan bata paving keramik. Dimensi paving yang digunakan adalah: panjang $=21 \mathrm{~cm}$, lebar $=10.5 \mathrm{~cm}$ dan ketebalan $=8 \mathrm{~cm}$.

\section{Alat dan Bahan Campuran}

Alat yang digunakan untuk mengaduk campuran $\mathrm{TiO}_{2}$ adalah sebuah mixer, sedangkan bahan utama berupa bubuk $\mathrm{TiO}_{2}$ anastase, water based resin dan air. Campuran $\mathrm{TiO}_{2}$ yang telah terbentuk dikuas secara merata pada permukaan paving.

\section{Jumlah Paving Block dan Durasi Pemaparan}

Sebanyak 80 buah paving yang telah dilapisi $\mathrm{TiO}_{2}$ digunakan dalam penelitian ini, Selain itu ditambahkan paving kontrol, paving kontrol (blank) merupakan paving tanpa dilapisi $\mathrm{TiO}_{2}$ yang digunakan sebagai pembanding dengan paving yang dilapisi $\mathrm{TiO}_{2}$. Hal ini berguna untuk melihat/membuktikan adanya proses fotokatalitik yang terjadi di permukaan paving block berlapis $\mathrm{TiO}_{2}$. Paving yang digunakan sebagai kontrol disamakan dari segi jumlah maupun perlakuannya dengan paving yang berlapis $\mathrm{TiO}_{2}$. Jadi ada 160 buah paving yang digunakan pada penelitian ini. Durasi pemaparan paving di lapangan dibagi menjadi 
empat bagian yaitu 6 jam, 12 jam, 18 jam dan 24 jam.

\section{Penentuan Konsentrasi Oksida Nitrogen ( $\mathrm{NO}$ dan $\mathrm{NO}_{2}$ )}

Oksida nitrogen di udara ambien yang diukur adalah $\mathrm{NO}$ dan $\mathrm{NO}_{2} . \mathrm{NO}_{2}$ diukur menggunakan Metode Griess Saltman Spectrofotometri. Gas $\mathrm{NO}_{2}$ di udara direaksikan dengan pereaksi Griess Saltman (absorban) membentuk senyawa yang berwarna ungu. Intensitas warna yang terjadi diukur dengan spektrofotometer pada panjang gelombang $550 \mathrm{~nm}$. Sedangkan gas NO dioksidasi dengan oksidator $\mathrm{KMnO}_{4}$ atau $\mathrm{K}_{2} \mathrm{Cr}_{2} \mathrm{O}_{7}$ sehingga membentuk $\mathrm{NO}_{2}$. Selanjutnya gas tersebut direaksi dengan pereaksi GriessSaltman. Pengambilan sampel dilakukan setiap satu jam sekali selama pemaparan.

\section{Pengukuran Intensitas Ultraviolet}

Pengukuran intensitas sinar ultraviolet (UV) dilakukan dengan menggunakan suatu instrumen solar radiometer UV A/B dalam satuan $\mu \mathrm{W} / \mathrm{cm}^{2}$. Sensor alat ukur dipasang vertikal (tegak lurus) terhadap sumber radiasi (matahari). Pengukuran dilakukan setiap 15 menit sekali selama pengambilan sampel di lapangan.

\section{Pengukuran Kelembaban dan Suhu}

Untuk menentukan kelembaban dan suhu, digunakan alat yang bernama Hygrotermometer, sebuah alat digital yang bisa mengukur kelembaban dan suhu sekaligus. Pengukuran dilakukan setiap 15 menit sekali selama pemaparan sampel di lapangan.

\section{Kecepatan Angin}

Untuk mengukur kecepatan angin di lapangan digunakan alat anemometer, dengan prinsip kerja adalah angin yang bertiup memutar balingbaling yang ada dialat dan sensor alat akan mengukur kecepatan putaran baling-baling tersebut. Pengukuran ini dilakukan setiap 15 menit sekali selama pemaparan sampel di lapangan.

\section{Preparasi Sampel Ion Nitrat dan Nitrit}

Sample ion nitrat dan nitrit yang berada di permukaan paving dilarutkan dengan aquades deionized, permukaan paving direndam selama lima menit dan kemudian dibilas. Volume air yang digunakan untuk setiap paving adalah \pm 200 mL. Larutan kemudian disaring menggunakan kertas saring dan disimpan dalam botol high density polyethylene didinginkan pada suhu $4{ }^{\circ} \mathrm{C}$ yang kemudian segera dianalisa dalam kurun waktu maksimum 48 jam.

Konsentrasi ion nitrat dan nitrit yang terbentuk dipermukaan paving diukur menggunakan alat Ion Chromatography (IC).

\section{pH dan Konduktivitas}

Sampel larutan hasil dari pelarutan ion nitrat dan nitrit yang terbentuk dipermukaan paving diukur $\mathrm{pH}$ menggunakan $\mathrm{pH}$ meter dan konduktivitasnya menggunakan conductivity meter.

\section{Kinetika Reaksi}

Kinetika reaksi pembentukan $\mathrm{HNO}_{3}{ }^{-}$ditentukan dengan menerapkan hukum laju reaksi. Reaksi pembentukan $\mathrm{HNO}_{3}{ }^{-}$secara fotokatalitik pada permukaan paving yang berlapis $\mathrm{TiO}_{2}$ disajikan pada persamaan reaksi (1). Reaksi fotokatalitik yang terjadi dipermukaan paving menunjukkan kinetika reaksi orde pertama dengan konstanta laju reaksi $k\left(\mathrm{NO}_{2}+\mathrm{TiO}_{2}\right)$ adalah $0,041 \pm 0,007$ $\mathrm{s}^{-1}$ (Laufs et al, 2010).

$\mathrm{NO}+\mathrm{NO}_{2}+\mathrm{O}_{2}+\mathrm{H}_{2} \mathrm{O} \longrightarrow 2 \mathrm{HNO}_{3}{ }^{-}$

maka hukum laju reaksi untuk persamaan diatas adalah:

$$
r=k[\mathrm{NO}]\left[\mathrm{NO}_{2}\right]\left[\mathrm{O}_{2}\right]\left[\mathrm{H}_{2} \mathrm{O}\right]
$$

dimana:

$r=$ laju reaksi

$k=$ konstanta laju reaksi

[ ] = molaritas zat

Konsentrasi $\mathrm{NO}$ dan $\mathrm{NO}_{2}$ ditentukan dari hasil pengukuran $\mathrm{NO}$ dan $\mathrm{NO}_{2}$ di lapangan saat pemaparan, untuk konsentrasi $\mathrm{O}_{2}$ ditentukan dari komposisi $\mathrm{O}_{2}$ yang ada di atmosfer, sedangkan untuk konsentrasi $\mathrm{H}_{2} \mathrm{O}$ ditentukan dari kelembaban yang terukur saat pemaparan 
yang dikonversi ke kelembaban spesifik yang selanjutnya dikali dengan berat udara spesifik.

\section{HASIL DAN PEMBAHASAN}

\section{Komposisi Optimum Campuran $\mathrm{TiO}_{2}$}

Dari hasil percobaan awal untuk menentukan komposisi optimum campuran $\mathrm{TiO}_{2}$ dihasilkan 9 buah paving yang memiliki berbagai variasi perbandingan antara $\mathrm{TiO}_{2}$, water based resin dan air. Berbagai variasi ini diberi kode $1 \mathrm{~K}, 2 \mathrm{~K}, 3 \mathrm{~K}$, ...9K.

Sebelum dilakukan uji ketahanan aus, dilakukan uji secara sederhana terlebih dahulu yaitu dengan cara fisik dengan menggesekkan jari pada permukaan paving yang dilapisi $\mathrm{TiO}_{2}$, lima buah paving dengan hasil terbaik dipisahkan, kelima buah paving terpilih tersebut $\mathbf{5 k}, \mathbf{6 k}, \mathbf{7 k}$, $\mathbf{8 k}$ dan 9k. Kelima paving tersebut dilakukan uji ketahanan aus. Hasil uji ketahanan aus dari masing-masing variasi paving terpilih ditampilkan pada Tabel 1.

Selanjutnya dihitung biaya yang ditimbulkan dari komposisi campuran $\mathrm{TiO}_{2}$ tersebut, informasi detail dari biaya tambahan dari $\mathrm{TiO}_{2}$ dan resin diperlihatkan pada Tabel 2.

Tabel 1. Komposisi Perbandingan $\mathrm{TiO}_{2}$, Water Based Resin dan Air per $1 \mathrm{~m}^{2 *}$

\begin{tabular}{|c|c|c|c|c|c|}
\hline \multirow{2}{*}{$\begin{array}{c}\text { Kode } \\
\text { paving }\end{array}$} & \multirow{2}{*}{$\begin{array}{c}\text { Jumlah } \\
\text { Paving } \\
\text { (Buah) }\end{array}$} & $\begin{array}{c}\text { TiO2 } \\
(\mathrm{gram})\end{array}$ & $\begin{array}{c}\text { WBR } \\
(\mathrm{mL})\end{array}$ & $\begin{array}{c}\text { Air } \\
(\mathrm{mL})\end{array}$ & $\begin{array}{c}\text { Kus } \\
\text { (mm/menit) }\end{array}$ \\
\hline $5 \mathrm{k}$ & 50 & 200 & 160 & 150 & 0,087 \\
\hline $6 \mathrm{k}$ & 50 & 250 & 250 & 375 & 0,085 \\
\hline $7 \mathrm{k}$ & 50 & 200 & 200 & 600 & 0,090 \\
\hline $8 \mathrm{k}$ & 50 & 150 & 150 & 200 & 0,090 \\
\hline $9 \mathrm{k}$ & 50 & 200 & 100 & 200 & 0,089 \\
\hline
\end{tabular}

* 1 meter persegi setara dengan 50 buah paving

Tabel 2. Estimasi Harga Komposisi $\mathrm{TiO}_{2}$ dan Water Based Resin Untuk Setiap $1 \mathrm{~m}^{2}$

\begin{tabular}{|c|c|r|r|r|}
\hline \multirow{2}{*}{$\begin{array}{c}\text { Kode } \\
\text { Paving }\end{array}$} & \multirow{2}{*}{$\begin{array}{c}\text { Jumlah } \\
\text { Paving } \\
\end{array}$} & \multicolumn{2}{|c|}{$\begin{array}{c}\text { Komposisi } \\
\text { (Buah) }\end{array}$} & \multirow{2}{*}{$\begin{array}{c}\text { TOTAL } \\
\text { (Rupiah }\end{array}$} \\
\hline $5 \mathrm{k}$ & 50 & 9000 & 6688 & 15688 \\
\hline $6 \mathrm{k}$ & 50 & 11250 & 10450 & 21700 \\
\hline $7 \mathrm{k}$ & 50 & 9000 & 8360 & 17360 \\
\hline $8 \mathrm{k}$ & 50 & 6750 & 6270 & 13020 \\
\hline $9 \mathrm{k}$ & 50 & 9000 & 4180 & 13180 \\
\hline
\end{tabular}

Dengan mempertimbangkan biaya dan ketahanan aus maka perbandingan komposisi campuran yang dipilih adalah paving dengan kode $9 k$.

Komposisi campuran optimum yang didapatkan selanjutnya dipakai untuk membuat campuran $\mathrm{TiO}_{2}$ yang akan dilapisi di permukaan paving. Jumlah $\mathrm{TiO}_{2}$ yang digunakan untuk setiap paving sekitar 4 gram. Gambar 6 dibawah ini memperlihatkan paving yang telah dilapisi oleh $\mathrm{TiO}_{2}$ sebanyak 4 gram.

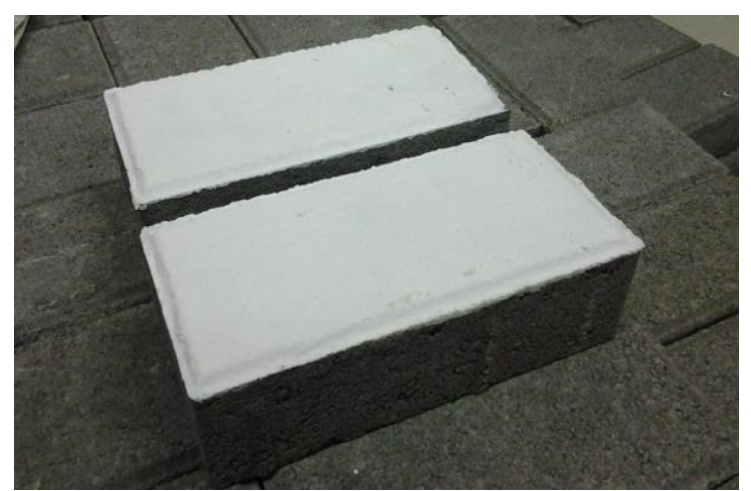

Gambar 6. Paving Block Berlapis $\mathrm{TiO}_{2}$

\section{Kondisi Lapangan Selama Pengukuran}

Pada Gambar 7 menunjukkan hasil pengukuran rata-rata per jam untuk konsentrasi $\mathrm{NO}, \mathrm{NO}_{2}$, $\mathrm{NO}_{\mathrm{x}}$ dan intensitas ultraviolet selama pemaparan paving di lapangan. Nilai $\mathrm{NO}_{\mathrm{x}}$ adalah penjumlahan konsentrasi $\mathrm{NO}$ dengan $\mathrm{NO}_{2}$. Dari grafik yang disajikan dapat dilihat pengaruh intensitas UV terhadap konsentrasi $\mathrm{NO}_{\mathrm{x}}$. Intensitas UV yang tinggi memberikan pengaruh kepada $\mathrm{NO}_{\mathrm{x}}$, dimana konsentrasi $\mathrm{NO}_{\mathrm{x}}$ turun pada saat intensitas UV yang tinggi. Turunnya konsentrasi $\mathrm{NO}_{\mathrm{x}}$ ini disebabkan terjadinya proses photochemical karena kehadiran UV.

Sementara itu, pada Gambar 8 dapat dilihat hubungan antara suhu dan kelembaban di lapangan, dimana pada saat suhu tinggi, kelembaban yang terukur rendah.

Hasil analisa korelasi menunjukkan bahwa semakin tinggi suhu, maka konsentrasi $\mathrm{NO}_{\mathrm{x}}$ yang terukur akan menjadi rendah. Sedangkan pada kelembaban yang rendah, hasil pengukuran $\mathrm{NO}_{\mathrm{x}}$ akan ikut rendah. Pada analisa korelasi hubungan antara kecepatan angin dan 
konsentrasi $\mathrm{NO}_{\mathrm{x}}$ yang terukur menjunjukkan bahwa hubungan kedua variabel ini lemah.

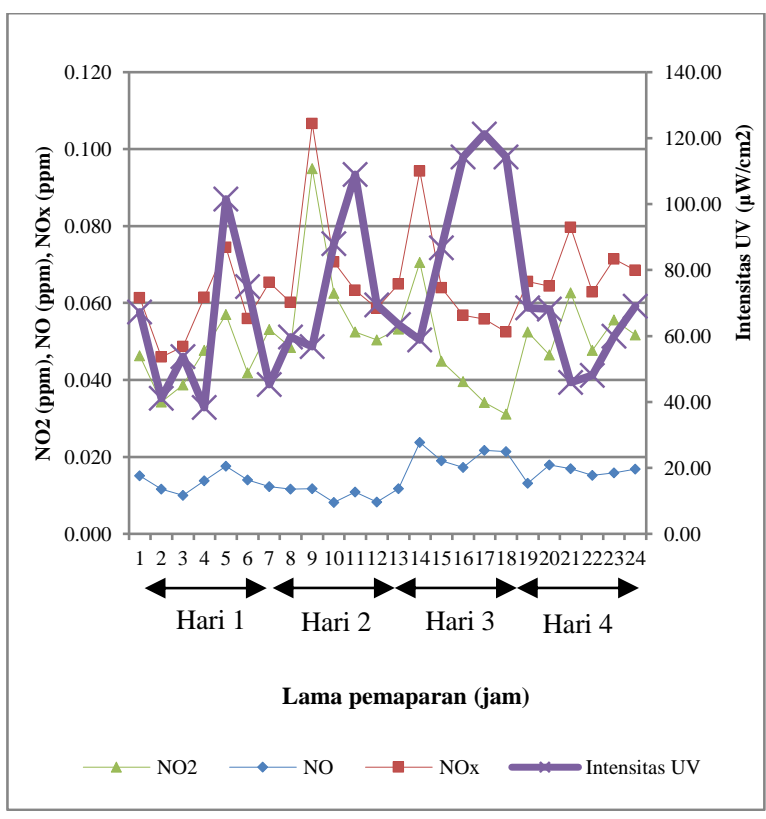

Gambar 7. Hasil Pengukuran $\mathrm{NO}, \mathrm{NO}_{2}, \mathrm{NO}_{\mathrm{x}}$ dan Intensitas UV Selama di Lapangan

Sebanyak 40 buah paving berlapis $\mathrm{TiO}_{2}$ yang digunakan dalam penelitan ini dan ada 40 buah paving tanpa dilapisi $\mathrm{TiO}_{2}$ yang digunakan sebagai pembanding. Perlakuaan dari kedua jenis paving tersebut diberlakukan secara sama. Pengambilan paving dari hasil pemaparan di lingkungan dilakukan pada jam ke 6, 12, 18 dan 24, dimana pada waktu tersebut diambil 10 buah paving berlapis $\mathrm{TiO}_{2}$ dan 10 buah paving tanpa $\mathrm{TiO}_{2}$ untuk selanjutnya akan diukur kandungan ion nitrat dan nitrit yang ada di permukaan paving tersebut.

Paving sebelum dan setelah pemaparan diukur kandungan ion nitrat dan nitritnya, dari hasil pengukuran didapatkan konsentrasi ion nitrat dan ion nitrit untuk paving tanpa $\mathrm{TiO}_{2}$ sebesar 0,181 dan $0,073 \mathrm{ppm}$.

Sedangkan untuk paving berlapis $\mathrm{TiO}_{2}, 0$ ppm untuk ion nitrat dan $0,013 \mathrm{ppm}$ untuk ion nitrit. Hasil pengukuran ion nitrat dan nitrit sebelum pemaparan ini dijadikan koreksi untuk menentukan besaran ion nitrat dan ion nitrit yang dihasilkan akibat proses fotokatalitik yang terjadi di permukaan paving.

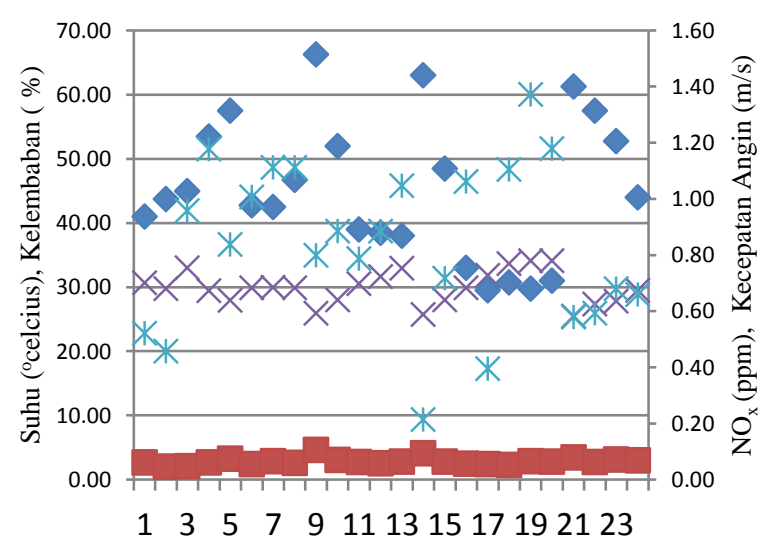

Lama pemaparan (jam)

$\times$ Suhu $\diamond$ Kelembaban $*$ Kecepatan Angin $\square$ Konsentrasi NOx Ambien

Gambar 8. Hubungan antara Suhu,

Kelembaban, Kecepatan Angin terhadap

Konsentrasi NOx Terkandung Pada Kedua Jenis Paving

Pada Gambar 9 diperlihatkan hasil pengukuran ion nitrat yang terkandung didalam kedua jenis paving yang digunakan. Konsentrasi ion nitrat pada paving $\mathrm{TiO}_{2}$ terlihat tinggi jika dibandingkan dengan konsentrasi ion nitrat paving tanpa $\mathrm{TiO}_{2}$. Bahkan semakin lama waktu pemaparan nilai ion nitrat pada paving dengan $\mathrm{TiO}_{2}$ bisa 6 kali lipat dibandingkan dengan paving tanpa $\mathrm{TiO}_{2}$. Hal ini membuktikan adanya proses fotokatalitik yang terjadi pada paving berlapis $\mathrm{TiO}_{2}$, namun pada paving tanpa $\mathrm{TiO}_{2}$ tetap ada ion nitrat yang terukur, kemungkinan ini disebabkan oleh pengaruh debu dan partikel lainnya yang terbawa oleh angin selama pemaparan sehingga teradsorp pada permukaan paving tanpa $\mathrm{TiO}_{2 .}$.

Kemampuan dari proses fotokatalitik $\mathrm{TiO}_{2}$ dihitung dari selisih ion nitrat yang terukur dari paving berlapis $\mathrm{TiO}_{2}$ dengan paving tanpa $\mathrm{TiO}_{2}$. Pada Gambar 10 diperlihatkan kemampuan fotokatalitik dari paving berlapis $\mathrm{TiO}_{2}$ dimana seiring dengan lamanya waktu pemaparan konsentrasi ion nitrat yang teradsorp pada permukaan paving semakin meningkat.

Untuk mengetahui laju reaksi pembentukan ion nitrat di permukaan paving berlapis $\mathrm{TiO}_{2}$ dihitung berdasarkan persamaan reaksi (1), dimana reaksi fotokatalitik yang terjadi 
dipermukaan paving menunjukkan kinetika reaksi orde pertama dengan konstanta kecepatan $k\left(\mathrm{NO}_{2}+\mathrm{TiO}_{2}\right)$ adalah $0,041 \pm 0,007 \mathrm{~s}^{-1}$ (Laufs et al, 2010).

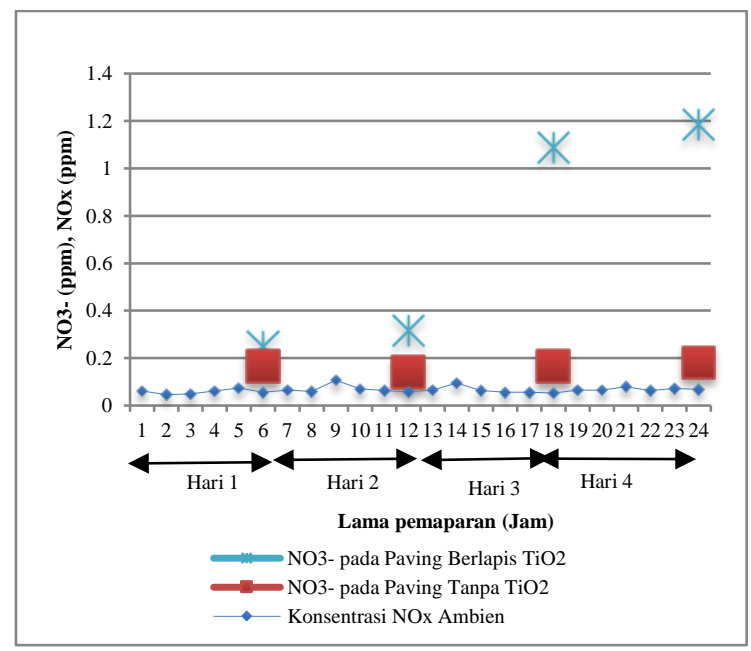

Gambar 9. Hasil Pengukuran Ion Nitrat yang

Dengan menerapkan hukum laju reaksi dan melalui pendekatan konsentrasi masing-masing senyawa yang ada pada reaksi pembentukan $\mathrm{HNO}_{3}{ }^{-}$(2), maka didapatkan kecepatan reaksi $r$ rata-rata selama proses pemaparan sebesar 3,49 $\times 10^{-7} \mathrm{M} / \mathrm{s}$. Sedangkan untuk mendapatkan kecepatan adsorpsi ditentukan dari kemampuan fotokatalitik $\mathrm{TiO}_{2}$ dibagi dengan luas permukaan aktif $\mathrm{TiO}_{2}$ dibagi dengan lama eksposur di lapangan.

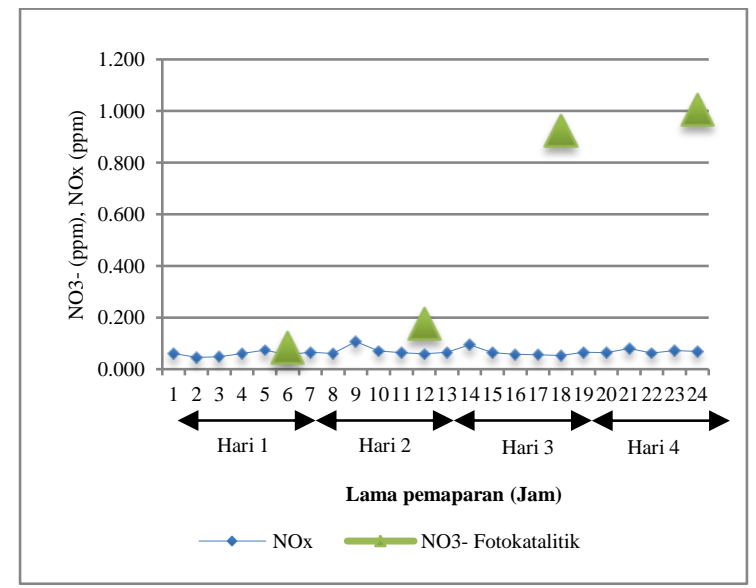

Gambar 10. Kemampuan Fotokatalitik Paving Berlapis $\mathrm{TiO}_{2}$ dan Konsentrasi $\mathrm{NO}_{x}$

Pada Gambar 11 disajikan grafik hasil perhitungan laju reaksi dan laju adsorpsi paving berlapis $\mathrm{TiO}_{2}$.

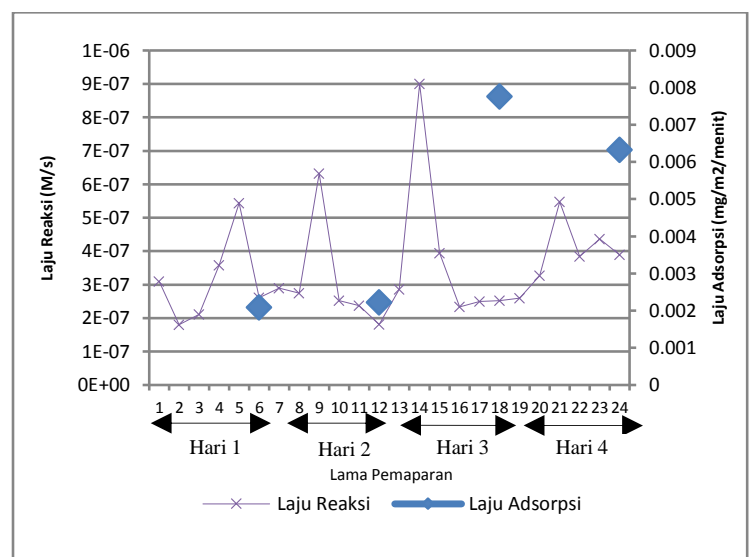

Gambar 11. Hasil Perhitungan Laju Reaksi dan Laju Adsorpsi Paving Berlapis $\mathrm{TiO}_{2}$

\section{KESIMPULAN}

Dari hasil penelitian menunjukkan bahwa paving block berlapis $\mathrm{TiO}_{2}$ mampu menurunkan konsentrasi NOx di udara ambien dengan harga yang murah memanfaatkan sinar matahari sebagai sumber energi aktifasi dan efek katalis dari $\mathrm{TiO}_{2}$, untuk mengendalikan $\mathrm{NO}$ dan $\mathrm{NO}_{2}$.

Kemampuan paving dalam mengadsorpsi ion nitrat dan ion nitrit sangat bervariasi selama proses pengukuran, dimana jumlah ion nitrat yang teradsorb lebih besar dari pada ion nitrit. Pada jumlah $\mathrm{TiO}_{2}$ sebanyak 4 gram untuk setiap paving atau 200 gram untuk setiap meter persegi mampu mengadsorpsi gas NOx dengan laju adsorpsi rata-rata sebesar $0,0046 \mathrm{mg} / \mathrm{m}^{2} /$ menit pada kondisi lingkungan dengan suhu rata-rata $29,89^{\circ} \mathrm{C}$, kelembaban rata-rata $45,31 \%$, kecepatan angin rata-rata $0,84 \mathrm{~m} / \mathrm{s}$, intensitas UV rata-rata sebesar $71,82 \mu \mathrm{W} / \mathrm{cm}^{2}$ dan konsentrasi gas $\mathrm{NO}_{\mathrm{x}}$ rata-rata sebesar 0,066 ppm. Biaya tambahan yang ditimbulkan dari penambahan $\mathrm{TiO}_{2}$ pada permukaan paving sebesar Rp. 13180/m².

Sebagai gambaran, sebuah studi menunjukkan bahwa biaya berobat untuk penyakit pernafasan dari polutan $\mathrm{NO}_{\mathrm{x}}$ adalah 64 - 315 Dollar Amerika untuk setiap ton $\mathrm{NO}_{\mathrm{x}}$ yang diemisikan (Mauzerall, dkk., 2005 dalam Laufs, dkk., 2010). Jika data ini diinterpolasikan, dapat diasumsikan bahwa setiap kilometer jalan berkontribusi 384 -1953 Dollar Amerika per tahun untuk biaya kesehatan atau setara 3,8 juta - 20 juta rupiah tiap tahunnya. Oleh karena itu, 
pemanfaatan paving berlapis $\mathrm{TiO}_{2}$ layak untuk dipertimbangkan, walaupun dengan pengaplikasian ini tidak menghilangkan pencemar $\mathrm{NO}_{\mathrm{x}}$ sampai $100 \%$.

\section{DAFTAR PUSTAKA}

Berdahl, P. and Akbari, H. 2008. "Evaluation of Titanium Dioxide as a Photocatalyst for Removing Air Pollutants". California Energy Commission, PIER EnergyRelated Environmental Research Program. CEC-500-2007-112.

Chusid, Michael. 2005. "FCSI, Next up.. SelfCleaning Concrete! Photocatalysts Can Keep Concrete Clean and Reduce Air Pollution" Concrete Décor.

Chen, Jun and Poon, Chi-sun. 2009. "Photocatalytic construction and building materials: From fundamentals to applications". Building and Environment. Vol. 44, 1899-1906

Chen, Jun. Kou, Shi-cong and Poon, Chi-sun. 2012. "Hydration and properties of nanoTiO2blended cement composites". Cement \& Concrete Composites. Vol. 34, 642-649

Diffey, B. L. (2002). Sources and measurement of ultraviolet radiation. Methods 28, 4-13.

Fujishima A, Hashimoto K, and Watanabe T. 1999. " $\mathrm{TiO}_{2}$ Photocatalysis: Fundamentals and Applications". BKC, Tokyo

Fujishima, A., Rao, T. N., dan Tryk, D. A. (2000). Titanium dioxide photocatalysis. Journal of Photochemistry and Photobiology C: Photochemistry Reviews, 1-21.

Hashimoto, K., Irie, H., dan Fujishima, A. (2005). TiO2 Photocatalysis: A Historical Overview and Future Prospects. Japanese Journal of Applied Physics, Vol. 44, No. 12, 8269-8285.

Laufs, S. Burgeth, G. Duttlinger, W. Kurtenbach, R. Maban, M. Thomas, C. Wiesen, P. Kleffmann, J. 2010. "Conversion of nitrogen oxides on commercial photocatalytic dispersion paints". Atmospheric Environmen. Vol. $44,2341-2349$

Paz, Yaron. 2010. "Application of $\mathrm{TiO}_{2}$ photocatalysis for air treatment: Patents' overview". Applied Catalysis B: Environmental. Vol. 99, 448-460

Shen, S., Maria, B., Bertram, J., dan Liv, H. (2012). Pervious Concrete with Titanium Dioxide as a Photocatalyst Compound for a greener urban road environment. Construction and Building Materials 35, pp. 874-883

Toulan, Emmanuel; Maze, Michel; Rousseau, Pascal. 2006. "Depolluting device with $\mathrm{TiO} 2$ photocatalyst particles in hydraulic binder coating activated by UV lamp for confined spaces" EP 1652827

Maggos Th, Kotzias D, J. G. Bartzis, P. Leva, A. Bellintani, Ch. Vasilakos. 2005. "Investigations of $\mathrm{TiO}_{2}$-containing Construction Materials for the Decomposition of NOx in Environmental Chambers". 5th International Conference on Urban Air Quality. Valencia (Spain). 29-31 March

McForet. (2012, Juni 7). Retrieved from McForet:

http://www.mcforet.com/Especialidades/ OFFNOx/tabid/3707/language/enGB/Default.aspx

Yu, Jimmy Chai-Mei. 2002. "Ambient Air Treatment by Titanium Dioxide $\left(\mathrm{TiO}_{2}\right)$ Based Photocatalyst in Hong Kong". Environmental Protection Department, HKSAR. AS 00-467

Zhao, Juan and Yang, Xudong. 2003. "Photocatalytic oxidation of indoor air purification: a literature review". Building and Environment. Vol. 38, 645-654 